\title{
Identification of Transcripts Involved in Resistance Responses to Leaf Spot Disease Caused by Cercosporidium personatum in Peanut (Arachis hypogaea)
}

\author{
M. Luo, P. Dang, M. G. Bausher, C. C. Holbrook, R. D. Lee, R. E. Lynch, and B. Z. Guo
}

First and fifth authors: University of Georgia, Department of Crop and Soil Sciences, Tifton 31793; second and third authors: U.S. Department of Agriculture-Agricultural Research Service (USDA-ARS), U.S. Horticultural Research Laboratory, Ft. Pierce, FL 34945; fourth author: USDA-ARS, Crop Genetics and Breeding Research Unit, Tifton, GA 31793; and sixth and seventh authors: USDA-ARS, Crop Protection and Management Research Unit, Tifton, GA 31793.

Accepted for publication 13 December 2004.

\begin{abstract}
Luo, M., Dang, P., Bausher, M. G., Holbrook, C. C., Lee, R. D., Lynch, R. E., and Guo, B. Z. 2005. Identification of transcripts involved in resistance responses to leaf spot disease caused by Cercosporidium personatum in peanut (Arachis hypogaea). Phytopathology 95:381-387.

Late leaf spot disease caused by Cercosporidium personatum is one of the most destructive foliar diseases of peanut (Arachis hypogaea) worldwide. The objective of this research was to identify resistance genes in response to leaf spot disease using microarray and real-time polymerase chain reaction (PCR). To identify transcripts involved in disease resistance, we studied the gene expression profiles in two peanut genotypes, resistant or susceptible to leaf spot disease, using cDNA microarray containing 384 unigenes selected from two expressed sequenced tag (EST) cDNA libraries challenged by abiotic and biotic stresses. A total of 112

spots representing 56 genes in several functional categories were detected as up-regulated genes $\left(\log _{2}\right.$ ratio $\left.>1\right)$. Seventeen of the top 20 genes, each matching gene with known function in GenBank, were selected for validation of their expression levels using real-time PCR. The two peanut genotypes were also used to study the functional analysis of these genes and the possible link of these genes to the disease resistance trait. Microarray technology and real-time PCR were used for comparison of gene expression. The selected genes identified by microarray analysis were validated by real-time PCR. These genes were more greatly expressed in the resistant genotype as a result of response to the challenge of $C$. personatum than in the susceptible genotype. Further investigations are needed to characterize each of these genes in disease resistance. Gene probes could then be developed for application in breeding programs for marker-assisted selection.
\end{abstract}

Early leaf spot caused by Cercospora arachidicola S. Hori (teleomorph Mycosphaerella arachidis Deighton) and late leaf spot caused by Cercosporidium personatum (Berk. \& M. A. Curtis) Deighton (teleomorph $M$. berkeleyi Jenk.) are the major destructive diseases of peanut (Arachis hypogaea) worldwide $(5,21,39)$. Epidemics of leaf spot diseases cause nearly complete defoliation and yield losses of $50 \%$ or more. Epidemics are affected by weather patterns such as hot and wet conditions (37). Control of leaf spot diseases in the United States has depended on multiple applications of fungicide, based either on a calendar schedule or a weather-based spray advisory (9). Effective seasonlong control of leaf spot disease can be maintained by applying a recommended fungicide every 10 to 14 days. However, repeated fungicide applications could cause a slow erosion of disease control due to a gradual loss of sensitivity in the target pathogen population and contribute to greater production costs and environmental pollution.

The development of resistant cultivars could be effective in decreasing production costs and improving product quality. In the United States, sources of resistance to leaf spot have been identified through extensive screening of germ plasm $(18,19)$. Previous studies suggested that the mechanisms of resistance to $C$. arachidicola and $C$. personatum were controlled by quantitative traits (22). To study the complexity of the gene expression and the

Corresponding author: B. Z. Guo; E-mail address: bguo@tifton.usda.gov

DOI: 10.1094/PHYTO-95-0381

This article is in the public domain and not copyrightable. It may be freely reprinted with customary crediting of the source. The American Phytopathological Society, 2005 interaction with environmental factors in resistant genotypes, we used cDNA microarrays developed from our expressed sequence tag (EST) project (27) to analyze the gene expression profiles and to identify functional genes in order to develop markers for marker-assisted selection.

ESTs are partial sequences of cDNA clones in an expressed cDNA library and could be used to identify all of the unique sequences (genes) in order to study their functions $(1,29)$. The identified unique cDNA sequences can be used to fabricate a cDNA microarray for functional study (38). Microarrays are used to analyze a sample for the presence of gene variations or mutations (genotyping), or for patterns of gene expression (2).

Because of the economic importance of leaf spot disease in peanut and the environmental impact of chemical control method, it is essential to understand peanut resistance mechanisms at the molecular level and to develop specific gene probes for use in breeding disease-resistant cultivars. In this paper, we report the identification and characterization of the expression patterns of the resistant genes or cDNAs related to the resistance or susceptibility to late leaf spot disease using microarray analysis and realtime polymerase chain reaction (PCR). The $384 \mathrm{cDNA}$ clones for microarray fabrication were selected as unique EST sequences with function of adversity resistance to biotic or abiotic stresses.

\section{MATERIALS AND METHODS}

Plant genotypes and treatments. Peanut lines C34-24 (F43916-10-3 × PI203396) and GT-YY20 were used as resistant or susceptible to leaf spot disease, respectively. Peanut seeds were surface-sterilized with $70 \%$ ethanol, rinsed with sterile water, and 
planted in pots with sterilized soil. The plants were kept in the greenhouse at a temperature of 25 to $30^{\circ} \mathrm{C}$. The pathogen C. personatum was isolated from leaves of susceptible line GT-YY20 with typical disease symptoms collected in a field trial. The spore suspension solution was prepared according to Zhang et al. (45). One-month-old seedlings were inoculated by a spraying suspension solution of $C$. personatum spores $\left(2 \times 10^{5}\right.$ spores per $\mathrm{ml}$ of sterile water). The inoculated pots were covered with a polyethylene sheet for approximately $48 \mathrm{~h}$ to create proper conditions for infection. Seedlings sprayed with sterile distilled water were treated as control. The responses of resistance or susceptibility to the disease were monitored for several weeks after the treatment. When the symptoms were observed in the susceptible lines, leaves were collected, bulked, and immediately frozen in liquid nitrogen and then stored in a freezer at $-80^{\circ} \mathrm{C}$.

Extraction of mRNA. Frozen leaves were ground in liquid nitrogen, and total RNA was isolated with TRIZOL reagent (Invitrogen, Carlsbad, CA) according to manufacturer's instructions. The amount and quality of the total RNA obtained was determined by spectrophotometry (optical density $=260 / 280$ ) and electrophoresis on a $1 \%$ agarose gel containing formaldehyde. The poly $\left(\mathrm{A}^{+}\right)$RNA was isolated from total RNA using DynaBeads Oligo (dT) 25 (Dynal, Oslo, Norway) according to the manufacturer's instructions. The concentration, purity, and integrity of $\operatorname{poly}\left(\mathrm{A}^{+}\right)$RNA were measured. The final concentration of poly $\left(\mathrm{A}^{+}\right)$RNA was adjusted to $0.5 \mu \mathrm{g} / \mu \mathrm{l}$ with diethylprocarbonate-treated water.

Microarray production. The 384 genes were selected from 1,852 ESTs (27) and used for duplicated array spots. Two EST cDNA libraries were constructed from leaves of C34-24 ( $C$. personatum challenged) and immature pod of A13 (Aspergillus flavus challenged under drought stress). The selected ESTs with known function were all related to putative adversity resistance genes. ESTs of unknown function with greater redundancy in the cDNA libraries were also included in the array. Four internal control genes were used in the microarray fabrication. These genes were ribosomal protein S27a, histone H3, NADP, and actin, which are common genes expressed in peanut leaves and seeds. The clones of the selected ESTs were rearrayed to a 384-well plate, and then resequenced to make certain that the rearrayed cDNA clones matched the original clones. The complete inserts from the 384 plasmid clones were amplified. The PCR product qualities were monitored by agarose gel electrophoresis. The purified PCR products with a concentration of $200 \mathrm{ng} / \mu \mathrm{l}$ in $3 \times$ $\mathrm{SSC}(1 \times \mathrm{SSC}$ is $0.15 \mathrm{M} \mathrm{NaCl}$ plus $0.015 \mathrm{M}$ sodium citrate) were spotted to aminosilane slides in duplication with solid-pins and single-strike method according to the protocol of EZ-rays (Apogent Discoveries, Hudson, NH) using a spotting robot (GeneTAC G3, Genomic Solution, Ann Arbor, MI). Each spot was replicated two times.

Probe labeling and hybridization. Fluorescent-labeled cDNA probes were prepared by reverse transcription (RT) of poly $\left(\mathrm{A}^{+}\right)$ RNA in the presence of Cy3- or Cy5-coupled aminoallyl-dUTP (Amersham Biosciences, Piscataway, NJ). The RT reaction was performed in a $40-\mu \mathrm{l}$ volume containing $2 \mu \mathrm{g}$ of poly $\left(\mathrm{A}^{+}\right) \mathrm{RNA}$, $2 \mu \mathrm{g}$ of oligo(dT) $)_{18-23}$ primer, $2 \mu \mathrm{l}$ of each dNTP mixture $(10 \mathrm{mM}$ each of dATP, dCTP, dGTP, and $2 \mathrm{mM}$ dTTP), $0.1 \mathrm{M}$ dithiothreitol, $1 \mathrm{mM}$ Cy5-dUTP or Cy3-dUTP, 40 units of RNase inhibitor, and 200 units of Superscript II reverse transcriptase (Invitrogen) in $1 \times$ reaction buffer. The poly $\left(\mathrm{A}^{+}\right) \mathrm{RNA}$ and primers were heated at $70^{\circ} \mathrm{C}$ for $5 \mathrm{~min}$ and chilled on ice before the remaining reaction components were added. The RT was performed for $1.5 \mathrm{~h}$ at $42^{\circ} \mathrm{C}$. After RT, the RNA was degraded by incubating at $65^{\circ} \mathrm{C}$ for $15 \mathrm{~min}$ after the addition of $5 \mu \mathrm{l}$ of $0.5 \mathrm{M}$ EDTA $(\mathrm{pH}$ 8.0) and $5 \mu$ of $1 \mathrm{~N} \mathrm{NaOH}$. The reaction was neutralized by the addition of $25 \mu \mathrm{l}$ of $1 \mathrm{M}$ Tris-HCL (pH 8.0). One hundred microliters of TE (10 mM Tris, $\mathrm{pH} \mathrm{8.0,} \mathrm{and} 1 \mathrm{mM}$ EDTA) was added to the neutralized samples. The labeled probes were purified with
Microcon YM-30 columns (Millipore, Billerica, MA) according to the manufacturer's instructions. The purified probes were suspended in $40 \mu \mathrm{l}$ of TE separately.

Before hybridization, the slides were UV cross-linked, bovine serum albumin-blocked, and DNA-denatured. Hybridization was carried out in a total volume of $150 \mu \mathrm{l}$ consisting of $2 \times \mathrm{SSC}$, $0.08 \%$ (wt/vol) sodium dodecyl sulfate (SDS), $6 \%$ (vol/vol) liquid block (Amersham Biosciences), and Cy3- and Cy5-labled probes. The labeled cDNAs in hybridization buffer were heated at $95^{\circ} \mathrm{C}$ for $2 \mathrm{~min}$ and quickly transferred to ice. The slide was placed in a hybridization chamber (GeneMachines, San Carlos, CA) and then transferred to the oven at 60 to $65^{\circ} \mathrm{C}$. After 8 to $12 \mathrm{~h}$ of hybridization, the slides were washed in $2 \times \mathrm{SSC}$ and $0.1 \%$ (wt/vol) SDS with gentle shaking, which was preheated to $55^{\circ} \mathrm{C}$. After $15 \mathrm{~min}$ of washing, the slides were further washed in $0.5 \times$ SSC and $0.05 \times$ SSC for $15 \mathrm{~min}$, respectively, at room temperature. The slides were spin dried and immediately scanned. Each experiment was repeated at least three times.

Microarray data analysis. Hybridized slides were scanned using a Scanarray Express scanner (Perkin-Elmer, Boston, MA) for Cy3 $(532 \mathrm{~nm})$ and Cy5 $(635 \mathrm{~nm})$ at a resolution of $10 \mu \mathrm{m}$ per pixel, generating two separate TIFF images. The overall intensities of $\mathrm{Cy} 3$ and $\mathrm{Cy} 5$ were normalized and corrected by the references according to the ratios of these internal control genes. The acquired images were further analyzed by ArrayInformatics Software (Perkin-Elmer) to obtain the intensities of fluorescent signals and the Cy5/Cy3 ratio. The differentially expressed genes were defined as follows: (i) the absolute value of the $\mathrm{Cy} 5 / \mathrm{Cy} 3$ $\log _{2}$ was more than 1 (the variation of gene expression was more than twofold), and (ii) either $\mathrm{Cy} 3$ or Cy5 signal value was required for more than 600. Multiple experiments were analyzed using the default options of hierchical clustering function of ArrayInformatics.

Real-time RT-PCR. Real-time PCR was used to confirm the gene expression data obtained from the microarray experiments by testing the expression levels. The relative abundance of genes differentially expressed in the microarray experiments were tested using real-time PCR. Total RNA from samples were treated with DNase (Qiagen, Valencia, CA) to remove DNA pollution, and subsequently purified with the RNeasy Cleanup Kit (Qiagen). One-step RT-PCR was performed from total RNA with the QuantiTect SYBR Green RT-PCR Kit (Qiagen) according to the manufacturer's instructions. Total volume of reaction was $25 \mu \mathrm{l}$ consisting of SYBR Green RT-PCR master mix, QuantiTect RT mix, and $0.5 \mu \mathrm{M}$ each primer. Gene-specific primers were designed using OligoPerfect Designer (Invitrogen). PCR assay was carried out with SYBR Green system in the DNA Engine Opticon (MJ Research, Waltham, MA). Cycling parameters were set up according to the recommendation of QuantiTect SYBR Green RT-PCR Kit. Melt curves were run immediately after the last PCR cycle to examine if the measurements were influenced by primer-dimer pairs.

A ubiquitin gene was used as an internal reference for calculating relative transcript abundance. Each reaction was repeated at least three times to access the reproducibility. The amplification curve was generated after analyzing the raw data and adjusting the cycle threshold $\left(C_{T}\right)$ value. For the description of the relative quantification, it is necessary to select an appropriate mathematical model. Herein the $2^{-\Delta \Delta C_{T}}$ method for comparing relative expression results between treatments in real-time PCR was applied (26). For amplicons designed to be less than $150 \mathrm{bp}$ and for which the primer and $\mathrm{Mg}^{2+}$ concentrations have been properly optimized, the efficiency is close to one. Therefore, the amount of target, normalized to the reference control and relative to a calibrator, is given by $R=2^{-\Delta \Delta C_{T}}$, where $\Delta \Delta C_{T}=\Delta C_{T}$ sample $\Delta C_{T}$ control.

The final value obtained was a measure of the fold change in gene expression for the particular gene of interest between the treated samples and the untreated samples. 


\section{RESULTS}

Comparison of gene expression between C34-24 (resistant) and GT-YY20 (susceptible) under $C$. personatum infection. Peanut cDNA microarrays were used to profile the gene expression patterns and to characterize the difference between fungal-challenged samples and control samples of resistant and susceptible genotypes. The cDNA microarray has 384 genes selected from 1,852 ESTs (27) sequenced from two cDNA libraries. One was constructed from leaves of C34-24 (challenged by late leaf spot pathogen) and another one was from immature pod of A13 (challenged under drought stress and infection of A. flavus). The majority of these selected genes are putative adversity resistant genes. Four internal control genes, ribosomal protein S27a, histone $\mathrm{H} 3$, NADP, and actin, are included in the microarray.

The poly $\left(\mathrm{A}^{+}\right)$RNA from the challenged seedlings labeled with Cy5-dUTP was compared with the control labeled with Cy3-dUTP. The twofold ratio of mean fluorescent intensity after normalization and subtraction from the background was used as criteria to select significantly expressed gene ( $\log _{2}$ value $>1$ as up-regulated gene, $\log _{2}$ value $<-1$ as down-regulated gene). Under the fungal challenging, there were 112 up-regulated spots (about 56 genes) and 129 down-regulated spots (about 65 genes) in C34-24 (Fig. 1), whereas GT-YY20 had 54 up-regulated spots (about 27 genes) and 32 down-regulated spots (about 16 genes) (Fig. 2). Further analyses indicated that there were 19 up-regulated genes and 5 down-regulated genes that were commonly expressed in both C34-24 and GT-YY20. To compare the differences of gene expression under fungal challenging, the $C$. personatum-inoculated samples from C34-24 and GT-YY20 were also analyzed (Fig. 3). In C34-24, there were 275 up-regulated spots (about 138 genes) and 76 down-regulated spots (about 38 genes) detected.

Up-regulated genes in C34-24. In C34-24 samples challenged by $C$. personatum, the up-regulated genes identified by microarray analyses were classified into several functional categories (Table 1). The results indicate that there were a large number of genes belonging to signaling components and defense response groups. In the up-regulated genes, 36 genes were homologous to the genes of known function by BLASTx (4) analysis ( $E$ value $<$ $e-10$ ). Among the top 20 up-regulated genes (Table 2) selected according to the ratio differences ( $\log _{2}$ ratio of mean spot), the majority of these genes had putative functions. Two genes' $E$

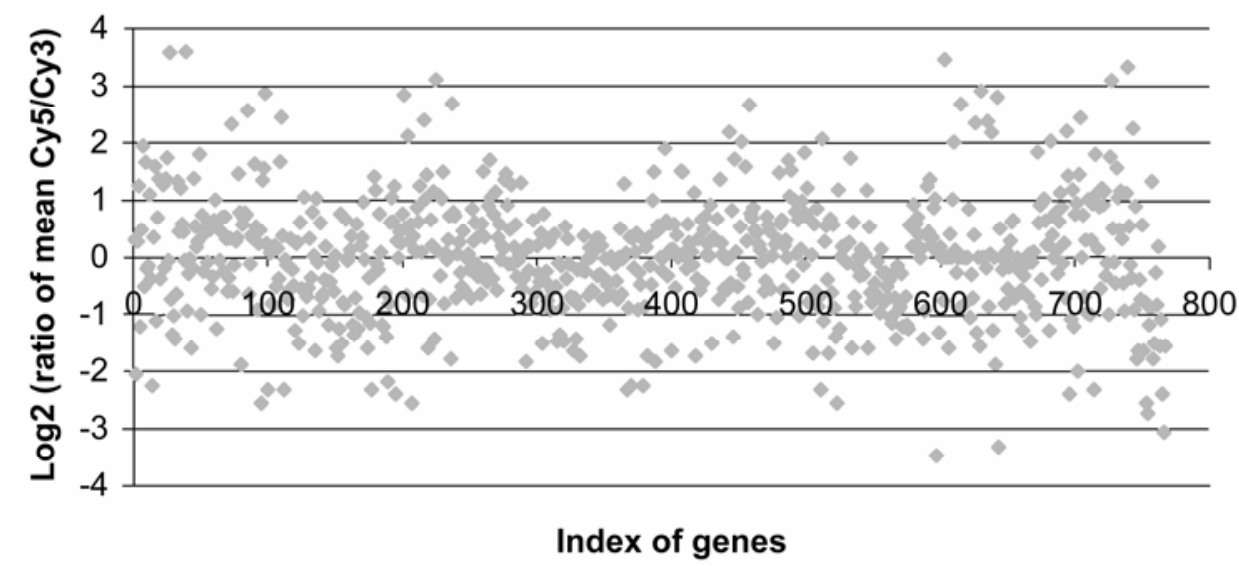

Fig. 1. Logarithmic scale ratio of mean fluorescent intensity for resistant genotype C34-24 challenged by Cercosporidium personatum after normalization and subtraction of background. Cy5: C34-24 challenged by C. personatum, Cy3: C34-24 control, and $x$ axis: an index number of each spot or gene placed in the cDNA microarray.

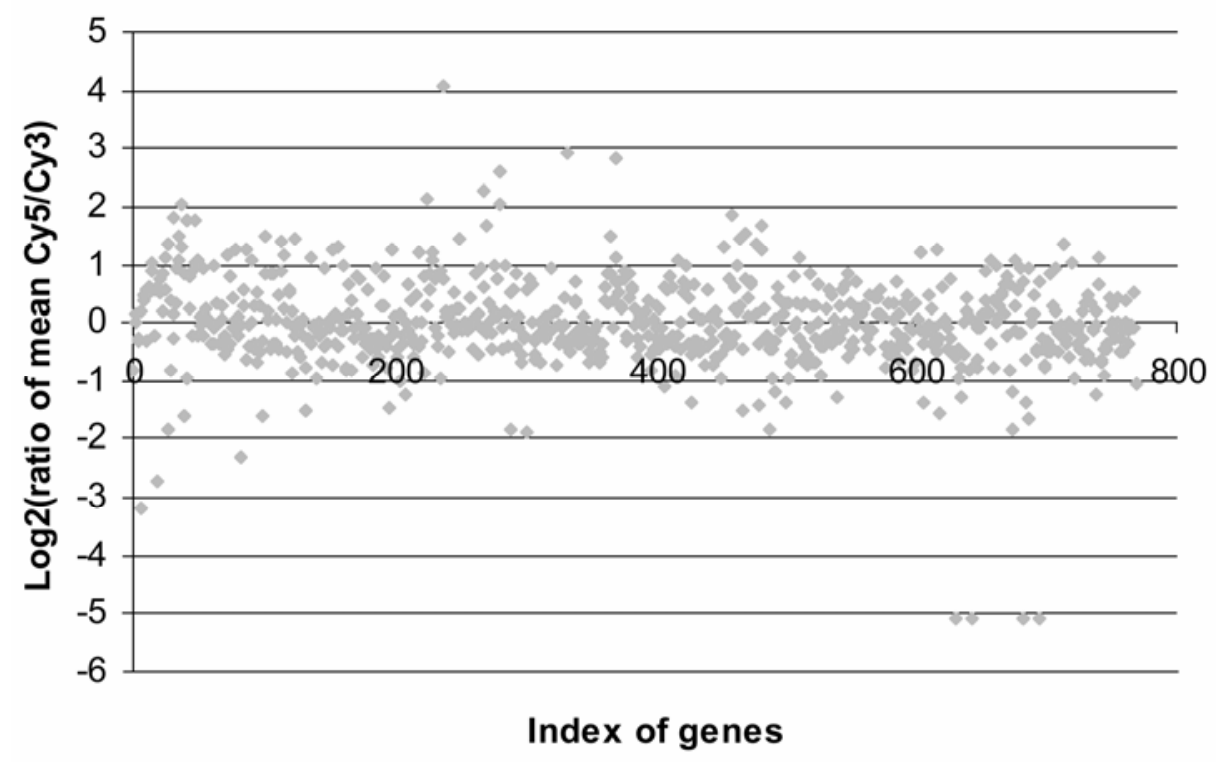

Fig. 2. Logarithmic scale ratio of mean fluorescent intensity for susceptible genotype GT-YY20 challenged by Cercosporidium personatum after normalization and subtraction of background. Cy5: GT-YY20 challenged by C. personatum, Cy3: GT-YY20 control, and $x$ axis: an index number of each spot or gene placed in the cDNA microarray. 
values were more than $e-10$, and three clones did not match any homologous sequences in GenBank.

Validation of the differential expressed genes. In comparison with the susceptible genotype, some genes were expressed significantly greater in microarray analysis in the resistant genotype challenged by the fungal pathogen. These microarray expression data were validated by real-time RT-PCR to test whether the results from microarray were the accurate gene expression levels or false positives (7), and whether the gene expression levels determined by microarray were associated with resistance in C3424. Seventeen genes that have homologous sequences in GenBank from the top 20 genes were selected for specific primer design. The two peanut genotypes were used for quantitative gene expression analyses using real-time PCR. Genotypes C34-24 and GT-YY20 were challenged by $C$. personatum in the greenhouse. A ubiquitin gene was used as an internal reference, and the relative quantity comparisons based on $C_{T}$ values (cycle threshold) from challenged and control samples in each genotype were conducted as the algorithm $R=2^{-\Delta \Delta C_{T}}$. The results indicated that the expression levels measured by real-time PCR of the majority genes were similar to the levels measured by microarray analysis $\left(2^{-\Delta \Delta C_{T}}>1\right)$ (Table 3), and the only exception was cytochrome P450 gene which had no differences between the induced and control samples. There were several genes expressed significantly greater in the induced samples compared with the control samples of the same genotype, such as defensin protein precursor, metallothionein, and allergen Arah3/Arah4 (Table 3). However, the expression levels of these genes were not significantly different between the resistant and the susceptible genotypes. Glutathione S-transferase 8 was expressed at an even greater level in the susceptible genotype than in the resistant genotype.

\section{DISCUSSION}

Microarray derived from ESTs can be a powerful tool for gene discovery and functional analysis $(20,46)$. The focus of this study was to select and identify differentially expressed genes using cDNA microarray by comparing two peanut genotypes, one resistant and one susceptible to late leaf spot disease. To identify genes associated with the resistance to leaf spot disease, we used the microarray containing 768 spots of 384 cDNA unigenes which partially came from the C34-24 leaf cDNA library challenged by $C$. personatum. This allowed us to screen for disease resistance genes in two genotypes infected with the pathogen. The expressions of some genes selected from the microarray analyses have been validated in these two genotypes by real-time RT-PCR. Even though the expressions of these genes were greater in the resistant genotype, further evaluation will be needed in more genotypes to confirm the association with the resistance. The information of the expression of the selected genes could be used to develop specific gene probes for use in breeding for disease resistance.

Gene differential expression in resistant and susceptible genotypes. DNA microarrays are increasingly being used in plant biology research for the comparative analysis of gene expression. The cDNA microarray has been used because of the low cost, and it has been the predominant method for the comparative analysis of gene expression in various plant biological processes, such as plant disease resistance, environmental stress responses, fruit and seed development, signaling in photomorphogenesis, and nitrate assimilation $(2,35)$. By comparison of the gene expression of the two genotypes, $C$. personatum was demonstrated to either stimulate or restrain gene expression in the resistant or susceptible genotypes, respectively. Therefore, in resistant genotype C34-24,

TABLE 1. Up-regulated genes of C34-24 challenged by Cercosporidium personatum from microarray analysis

\begin{tabular}{|c|c|}
\hline Class of function & Putative genes \\
\hline Secondary metabolism & $\begin{array}{l}\text { Caffeic acid O-methyltransferase, putative } \\
\text { flavanone 3-hydroxylase }\end{array}$ \\
\hline Stress proteins & $\begin{array}{l}\text { Cytochrome } \mathrm{p} 450 \text {, low temperature and salt } \\
\text { responsive protein LTI6B }\end{array}$ \\
\hline Heat shock proteins & $\begin{array}{l}\text { Heat shock protein } 81-2 \text {, cell-autonomous heat } \\
\text { shock cognate protein } 70\end{array}$ \\
\hline Signaling components & $\begin{array}{l}\text { Calcium binding protein, leucine-rich receptor-like } \\
\text { protein kinase, mannose/glucose-binding lectin } \\
\text { precursor, leucine-rich repeat, transmembrane } \\
\text { protein, protein kinase ATN1-like protein, } \\
\text { pyruvate kinase, indole-3-acetic acid-induced } \\
\text { protein, salicylic acid-induced protein, auxin- } \\
\text { induced protein }\end{array}$ \\
\hline Control of transcription & $\begin{array}{l}\text { Putative RING zinc finger protein, myb family } \\
\text { transcription factor, bzip transcription factor } 6\end{array}$ \\
\hline Defense response & $\begin{array}{l}\text { Bax inhibitor, glutathione S-transferase (GST 8, } \\
\text { GST 9), superoxide dismutase [Cu-Zn], oxygen- } \\
\text { evolving enhancer protein 2, glycosyl hydrolase } \\
\text { family } 19 \text { (chitinase), pathogenesis-related } \\
\text { protein }(3,10) \text {, disease-resistant-related protein, } \\
\text { metallothionein, putative senescence-associated } \\
\text { protein, putative leucine-rich repeat protein }\end{array}$ \\
\hline Unclassified protein & $\begin{array}{l}\text { Allergen Arah } 2.02 \text {, allergen Gly m Bd } 28 \mathrm{~K} \text {, seed } \\
\text { maturation protein LEA } 4 \text {, ankyrin repeat- } \\
\text { containing protein, allergen Arah3/Arah4 }\end{array}$ \\
\hline
\end{tabular}

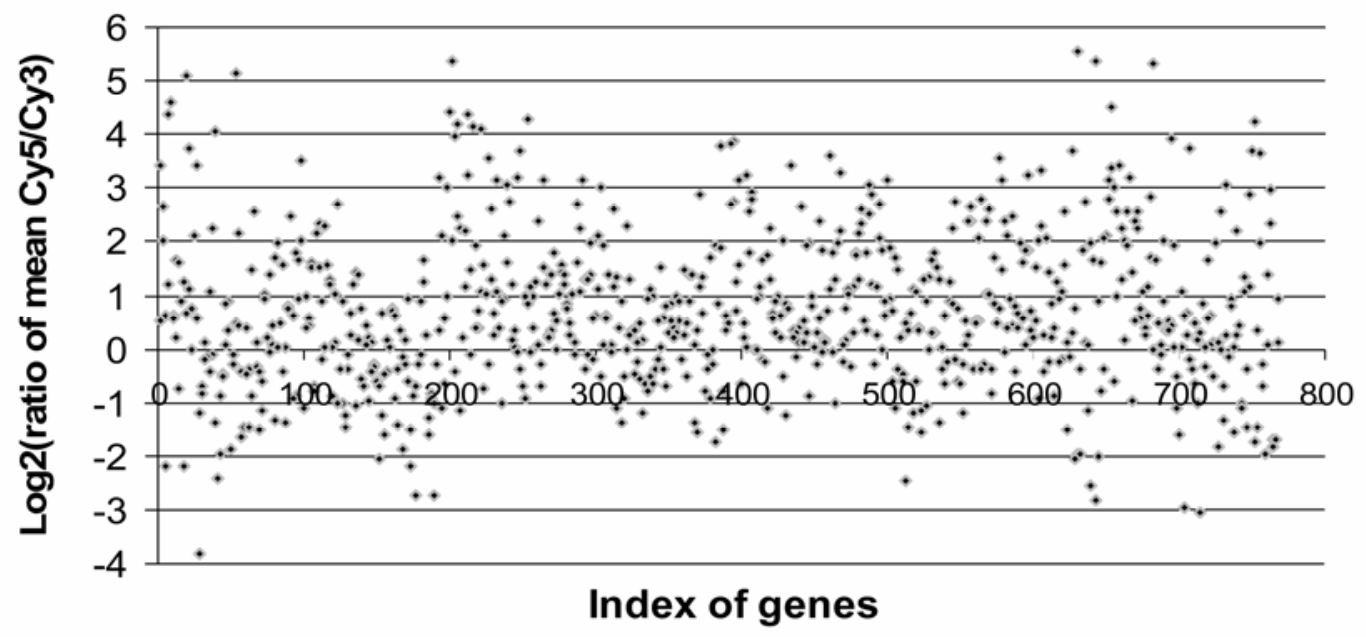

Fig. 3. Logarithmic scale ratio of mean fluorescent intensity for C34-24 and GT-YY20 challenged by Cercosporidium personatum after normalization and subtraction of background. Cy5: C34-24 challenged by C. personatum, Cy3: GT-YY20 challenged by $C$. personatum, and $x$ axis: an index number of each spot or gene placed in the cDNA microarray. 
more up-regulated genes were detected, and there were more down-regulated genes in susceptible genotype GT-YY20. Some genes expressed in both resistant and susceptible genotypes by microarray analysis, and several of the putative disease resistant genes, such as glycosyl transferase family protein (17) and defensin protein precursor (11), were also validated in both genotypes by real-time PCR. Superoxide dismutase [Cu-Zn] and glutathione $\mathrm{S}$-transferase 8 , which were significantly expressed in both genotypes, have been reported as antioxidative proteins extensively in plants responding to biotic and abiotic stresses $(3,13)$, although it is not clear why glutathione $S$-transferase 8 expressed even greater in the susceptible genotype GT-YY20. The greater expression of glutathione S-transferase 8 in GT-YY20 may be associated with other resistance traits (24).

Among the validated genes, a lipid-transfer protein precursor showed evident differences between the resistant and susceptible

TABLE 2. Up-regulated genes in C34-24 challenged by Cercosporidium personatum from microarray screening of gene expression

\begin{tabular}{|c|c|c|c|c|}
\hline Clone & Closest accession hit $^{\mathrm{a}}$ & Primary description ${ }^{b}$ & $E$ value by BLASTx & $\log _{2}$ (ratio of mean spot) \\
\hline UTPPI012_B07 & AAM65074 & Bax inhibitor-1 like protein & $2 e-079$ & 3.46 \\
\hline UTPPI012_A08 & T51098 & Hypothetical protein p85rf & $4 e-026$ & 3.30 \\
\hline UTPL001_E06 & XP_165433 & Similar to myeloid/lymphoid & 2.5 & 3.15 \\
\hline UTPL004_C09 & $\mathrm{T} 51144$ & Lipid-transfer protein precursor & $7 e-027$ & 3.10 \\
\hline UTPL006_D10 & No & No & & 2.98 \\
\hline UTPL001_D03 & No & No & & 2.95 \\
\hline UTPPI008_F04 & NP_188086 & Cytochrome P450 & $9 e-053$ & 2.84 \\
\hline UTPLN023_C02 & JW0084 & Superoxide dismutase $[\mathrm{Cu}-\mathrm{Zn}]$ & $4 e-061$ & 2.82 \\
\hline UTPLN023_D01 & AAO23085 & Leucine-rich repeat protein & $1 e-026$ & 2.73 \\
\hline UTPLN023_B05 & NP_189531 & Leucine-rich repeat protein family & 0.29 & 2.69 \\
\hline UTPPI003_B01 & AAL35366 & Defensin protein precursor & $2 e-023$ & 2.62 \\
\hline UTPPL003_3B3 & P33079 & Auxin-induced protein $10 \mathrm{~A} 5$ & $6 e-033$ & 2.57 \\
\hline UTPPI008_D07 & NP_188317 & Glycosyl hydrolase family 19 & $4 e-067$ & 2.53 \\
\hline UTPL006_F03 & AAG34798 & Glutathione S-transferase 8 & $3 e-026$ & 2.42 \\
\hline UTPPI002_B02 & JQ2128 & Metallothionein & $5 e-019$ & 2.23 \\
\hline UTPPI008_F09 & AAM46958 & Allergen Arah3/Arah4 & $9 e-096$ & 2.17 \\
\hline UTPL003_B01 & No & No & & 2.13 \\
\hline UTPPI002_F08 & AAL32031 & Drought-induced protein RPR-10 & $9 e-013$ & 2.09 \\
\hline UTPLN023_H08 & P32292 & Indole-3-acetic acid-induced protein ARG-2 & $7 e-015$ & 1.97 \\
\hline UTPPI005_F07 & BAB63949 & Pathogenesis-related 10 & $6 e-053$ & 1.96 \\
\hline
\end{tabular}

a Accession number from GenBank. No indicates no hit in GenBank.

${ }^{b}$ Description of the putative function. No indicates no putative function described or unknown function.

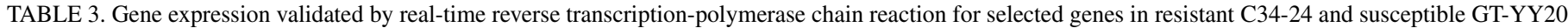

\begin{tabular}{|c|c|c|c|c|c|}
\hline Clone & Closest accession description & Primers $\left(5^{\prime}-3^{\prime}\right)$ & Length (bp) & $\begin{array}{l}\mathrm{C} 34-24 \\
2^{-\Delta \Delta C_{T}}\end{array}$ & $\begin{array}{l}\text { GT-YY20 } \\
2^{-\Delta \Delta C_{T}}\end{array}$ \\
\hline UTPL002_A11 & Ubiquitin & $\begin{array}{l}\text { F: AAGCCGAAGAAGATCAAGCAC } \\
\text { R: GGTTAGCCATGAAGGTTCCAG }\end{array}$ & 145 & 1.00 & 1.00 \\
\hline UTPPI012_B07 & Bax inhibitor-1 like protein & $\begin{array}{l}\text { F: TCTCTCCCGTCGTTCAGAATC } \\
\text { R: TGCATCCAGCTGACGTAAGAA }\end{array}$ & 132 & 10.34 & 0.60 \\
\hline UTPPI012_A08 & Hypothetical protein $\mathrm{p} 85 \mathrm{rf}$ & $\begin{array}{l}\text { F: TCTGTGCCGTACATCGCTAC } \\
\text { R: TATCAAGCTTCTCGGCCTTC }\end{array}$ & 114 & 3.78 & 0.80 \\
\hline UTPL001_E06 & Similar to myeloid/lymphoid & $\begin{array}{l}\text { F: GACATTGCAGAGGCACGTAA } \\
\text { R: GGAATTGGCACACCTGAAAC }\end{array}$ & 134 & 2.43 & 0.002 \\
\hline UTPL004_C09 & Lipid-transfer protein precursor & $\begin{array}{l}\text { F: AGGAAGCGGATACCACACAG } \\
\text { R: TCGCCTAAGTGGAGGTCCTA }\end{array}$ & 131 & 25.46 & 0.01 \\
\hline UTPPI008_F04 & Cytochrome P450 & $\begin{array}{l}\text { F: TGGGCTTACTCGAAATACCG } \\
\text { R: GCATTATCACCCCAAAGTCC }\end{array}$ & 123 & 0.90 & 0.04 \\
\hline UTPLN023_C02 & Superoxide dismutase $[\mathrm{Cu}-\mathrm{Zn}]$ & $\begin{array}{l}\text { F: CGCATTTCAACCCGAATAAC } \\
\text { R: TGCTTATCGACGATTGTTGC }\end{array}$ & 124 & 27.86 & 8.17 \\
\hline UTPLN023_D01 & Leucine-rich repeat protein & $\begin{array}{l}\text { F: AAGTTCACGTTGCCATCTCC } \\
\text { R: TTCCAGGTACTGGAGATGGTG }\end{array}$ & 116 & 6.50 & 0.88 \\
\hline UTPLN023_B05 & Leucine-rich repeat protein family & $\begin{array}{l}\text { F: CCATGTTACCTGTGACTCCAAC } \\
\text { R: TTCCAGGTACTGGAGATGGTG }\end{array}$ & 116 & 5.54 & 0.90 \\
\hline UTPPI003_B01 & Defensin protein precursor & $\begin{array}{l}\text { F: TAATGGCATCGCTCTCTTCC } \\
\text { R: ACACTCCTTTGAAGCGATGG }\end{array}$ & 139 & 9.06 & 7.94 \\
\hline UTPPI006_E09 & Auxin-induced protein $10 \mathrm{~A} 5$ & $\begin{array}{l}\text { F: TCGTTTATCCGGCATCGTA } \\
\text { R: TAGGGATCACAAACCGCTTC }\end{array}$ & 119 & 1.48 & 0.23 \\
\hline UTPPI008_D07 & Glycosyl hydrolase family 19 & $\begin{array}{l}\text { F: CGCCATCCCTATTTACTGGA } \\
\text { R: ACGTGTGTATTGCTGCTTGG }\end{array}$ & 128 & 18.64 & 4.82 \\
\hline UTPL006_F03 & Glutathione S-transferase GST8 & $\begin{array}{l}\text { F: CTTGGGCCAAAAGGTGTATG } \\
\text { R: TTTCCATCACCGGAAAACAC }\end{array}$ & 130 & 4.66 & 55.04 \\
\hline UTPPI002_B02 & Metallothionein & $\begin{array}{l}\text { F: GGCTGCAAGATGTACCCAGA } \\
\text { R: TCAGCTGGAACACCCATTTC }\end{array}$ & 122 & 3.03 & 6.38 \\
\hline UTPPI008_F09 & Allergen Arah3/Arah4 & $\begin{array}{l}\text { F: AAGAGCCTGCACAACAAGGAC } \\
\text { R: GAGATCACCCTCATCGAAACG }\end{array}$ & 128 & 2.39 & 2.27 \\
\hline UTPPI002_F08 & Drought-induced protein RPR-10 & $\begin{array}{l}\text { F: GCCCTGGAACTGTCAAGAAG } \\
\text { R: CTCTTGGAACCCTGTTCCTC }\end{array}$ & 134 & 8.88 & 0.48 \\
\hline UTPLN023_H08 & $\begin{array}{l}\text { Indole-3-acetic acid-induced } \\
\text { protein ARG-2 }\end{array}$ & $\begin{array}{l}\text { F: TATGGCTCGTTCTTTCTCTGC } \\
\text { R: CCTTCTCTTCCGTCGTCTTTG }\end{array}$ & 149 & 6.19 & 0.10 \\
\hline UTPPI005_F07 & Pathogenesis-related 10 & $\begin{array}{l}\text { F: ACAGCGTTGTTGGAGGAGTG } \\
\text { R: GCTTTGCATCTCCTTTGGTG }\end{array}$ & 135 & 20.82 & 0.06 \\
\hline
\end{tabular}


genotypes. This protein has been reported to have antifungal activity in other plants $(15,28,31)$. One other gene showing a large difference in expression was pathogenesis-related 10 which is a defense-related gene (32). Other disease resistance genes, such as glycosyl hydrolase family protein, leucine-rich repeat protein, and leucine rich repeat protein family $(10,14)$, were also found with greater expression. The gene encoding glycosyl hydrolase was expressed significantly great in both resistant and susceptible genotypes challenged by $C$. personatum; however, the expression level was much greater in the resistant genotype C34-24. Among the validated genes, the clone UTPPI012_A08 (hypothetical protein $\mathrm{p} 85 \mathrm{RF}$ ) has homology with a pathogenesis-related protein gene $(E$ value $=1 e-019)$ in kidney bean (36). The clone UTPPI002_F08 (drought-induced protein RPR-10) has homology with a pathogenesis-related protein gene $(E$ value $=6 e-013)$ of the PR10 class from Lupinus luteus (6). Auxin-induced protein 10A5 and indole-3-acetic acid-induced protein ARG-2 have not yet been proven to be involved in plant disease resistance, and further functional characterization is needed.

Analytic methods of gene screening. The traditional genetic method based on phenotypic characterization has indicated that the resistance to late leaf spot is controlled by quantitative trait loci (22), even though those reports could not identify the specific genes involved in the resistance. Our previous EST research (27) revealed the gene expression profiles in plants under abiotic and biotic stresses, but failed to identify the specific genes involved in the resistance to leaf spot disease. In this research, we used the combination of the two techniques, cDNA microarray and realtime PCR, to obtain information that may be used to identify the differentially expressed genes that may control resistance to leaf spot disease.

BLASTx analysis provides the putative function of differentially expressed genes identified by microarray analysis. Realtime PCR was used to validate the gene expression data of microarray analysis in order to eliminate the false positive. Seventeen of the top 20 genes were selected for real-time PCR analysis in both resistant and susceptible genotypes. The results indicted that the selected genes, which expressed significantly differently in microarray analysis, had similar expression using RT-PCR analysis as well as microarray (Table 3 ). However, there were exceptions (Table 3 ). These results suggest that gene expression analysis using cDNA microarray was not always consistent with the results of real-time PCR analysis. This indicates that cDNA microarray can be used to efficiently screen for differentially expressed genes. However, the genes identified from cDNA microarray also need to be validated by real-time PCR in order to minimize the false positive genes (38). Several genes had significant differences between the induced and the control samples, and few differences were observed between the resistant and the susceptible genotypes. These results suggest that the quantitative comparison of gene expression should be verified by real-time PCR to confirm the association of the selected gene with the resistant trait.

Tissue-specific gene expression. While analyzing the gene expression in the resistant cultivars with microarray, we found some significantly expressed genes that were selected from the cDNA library of peanut immature-pod. Several genes have been validated by real-time PCR, including Bax inhibitor-1 like protein, hypothetical protein $\mathrm{p} 85 \mathrm{RF}$, defensin protein precursor, auxininduced protein 10A5, glycosyl hydrolase family 19, metallothionein, allergen Arah3/Arah4, drought-induced protein RPR-10, and pathogenesis-related 10 . These results indicate that the expression of these genes may not be tissue-specific. Other genes, such as cytochrome $\mathrm{P} 450$, showed significant expression by microarray analysis, and they did not show significant expression in real-time PCR analysis. We believe that cross hybridization between different cDNA fragment probes with homologous regions may be causing the false positives in the microarray hy- bridization. Therefore, to avoid false results, the synthetic oligonucleotide microarray would be the new generation of this new technology with more specificity $(12,25)$. The results in this study also suggest that the microarray from amplified cDNA fragments can be used as a primary screening method of differential expression genes, although the screened genes need to be validated.

Although this technology is still in its infancy, microarray has been used widely for genome-wide gene expression analyses. This technology has been applied to characterize transcript abundance, complexity, and stability (47), to identify novel target genes and pathways that are associated with biological process $(8,23,30,34,43)$, to determine the regulatory elements of genes and pathways $(16,46)$, to characterize gene functions by profiling genetic mutants $(41,42)$, and to profile gene expression pattern as a marker to predict biological performance $(33,40)$. The lack of genomic information for peanut has hindered the progress in developing genetic tools and information for breeding and genetic enhancement of peanut (44). This research has demonstrated the potential usefulness of the application of these genetic tools, ESTs and microarray, in comparative analysis of gene expression in different genotypes.

\section{ACKNOWLEDGMENTS}

We thank X. Liang for assistance and helpful discussion, J. Mozoruk for technical help in array production, and E. Harris and K. Lewis for technical assistance in the field and the laboratory. This research is supported by USDA Specific Cooperative Agreement 58-6602-1-213 with the University of Georgia, and partially supported by funds provided by USDA-Agricultural Research Service, Georgia Peanut Commission, and National Peanut Foundation. Mention of trade names or commercial products in this publication is solely for the purpose of providing specific information and does not imply recommendation or endorsement by the U.S. Department of Agriculture.

\section{LITERATURE CITED}

1. Adams, M. D., Kelley, J. M., Gocayne, J. D., Dubnick, M., Polymeropoulos, M. H., Xiao, H., Merril, C. R., Wu, A., Olds, B., Moreno, R. F., Kerlavage, A. R., McCombie, W. R., and Venter, J. C. 1991. Complementary DNA sequencing: Expressed sequence tags and human genome project. Science 252:1651-1656.

2. Aharoni, A., and Vorst, O. 2002. DNA Microarrays for functional plant genomics. Plant Mol. Biol. 48:99-118.

3. Alscher, R. G., Erturk, N., and Heath, L. S. 2002. Role of superoxide dismutases (SODs) in controlling oxidative stress in plants. J. Exp. Bot. 53:1331-1341

4. Altschul, S. F., Gish, W., Miller, W., Myers, E. W., and Lipman, D. J. 1990. Basic local alignment search tool. J. Mol. Biol. 215:403-410.

5. Backman, P. A., and Crawford, M. A. 1984. Relationship between yield loss and severity of early and late leaf spot diseases of peanut. Phytopathology 74:1101-1103.

6. Biesiadka, J., Sikorski, M. M., Bujacz, G., and Jaskolski, M. 1999. Crystallization and preliminary x-ray structure determination of Lupinus luteus PR10 protein. Acta Crystallogr. Sect. D Biol. Crystallogr. 55:19251927.

7. Bustin, S. A. 2000. Absolute quantification of mRNA using real-time reverse transcription polymerase chain reaction assays. J. Mol. Endocrinol. 25:169-193.

8. Cheong, Y. H., Chang, H.-S., Gupta, R., Wang, X., Zhu, T., and Luan, S. 2002. Transcriptional profiling reveals novel interactions between wounding, pathogen, abiotic stress, and hormonal responses in Arabidopsis. Plant Physiol. 129:661-677.

9. Culbreath, A. K., Stevenson, K. L., and Brenneman, T. B. 2002. Management of late leaf spot of peanut with benomyl and chlorothalonil: A study in preserving fungicide utility. Plant Dis. 86:349-355.

10. Dangl, J. L., and Jones, J. D. 2001. Plant pathogens and integrated defence responses to infection. Nature 411:826-833.

11. Do, H. M., Lee, S. C., Jung, H. W., Sohn, K. H., and Hwang, B. K. 2004. Differential expression and in situ localization of a pepper defensin (CADEF1) gene in response to pathogen infection, abiotic elicitors and environmental stresses in Capsicum annuum. Plant Sci. 166:1297-1305.

12. Duggan, D. J., Bittner, M., Chen, Y., Meltzer, P., and Trent, J. M. 1999. Expression profiling using cDNA microarrays. Nat. Gen. (Suppl.) 21: $10-14$. 
13. Edwards, R., Dixon, D. P., and Walbot, V. 2000. Plant glutathione S-transferases: Enzymes with multiple functions in sickness and in health. Trends Plant Sci. 5:193-198.

14. Fluhr, R. 2001. Sentinels of disease, plant resistance genes. Plant Physiol. 127:1367-1374.

15. Ge, X., Chen, J., Li, N., Lin, Y., Sun, C., and Cao, K. 2003. Resistance function of rice lipid transfer protein LTP110. J. Biochem. Mol. Biol. 36:603-607.

16. Harmer, S. L., Hogenesch, J. B., Straume, M., Chang, H. S., Han, B., Zhu, T., Wang, X., Kreps, J. A., and Kay, S. A. 2000. Orchestrated transcription of key pathways in Arabidopsis by the circadian clock. Science 290:21102113.

17. Heil, M., and Bostock, R. M. 2002. Induced systemic resistance (ISR) against pathogens in the context of induced plant defences. Ann. Bot. 89:503-512.

18. Holbrook, C. C., and Anderson, W. F. 1995. Evaluation of a core collection to identify resistance to late leaf spot in peanut. Crop Sci. 35:17001702.

19. Holbrook, C. C., and Stalker, H. T. 2003. Peanut breeding and genetic resources. Plant Breed. Rev. 22:297-356.

20. Horvath, D. P., Wisman, E., West, M., and Schaffer, R. 2003. Arabidopsis microarrays identify conserved and differentially expressed genes involved in shoot growth and development from distantly related plant species. Plant J. 34:125-134.

21. Jackson, C. R., and Bell, D. K. 1969. Diseases of peanut (groundnut) caused by fungi. Univ. Ga. Coll. Agric. Exp. Stn. Res. Bull. 56:1-5.

22. Kornegay, J. L., Beute, M. K., and Wynne, J. C. 1980. Inheritance of resistance to Cercospora arachidicola and Cercosporidium personatum in six Virginia-type peanut lines. Peanut Sci. 7:4-9.

23. Kreps, J. A., Wu, Y., Chang, H. S., Zhu, T., Wang, X., and Harper, J. F. 2002. Transcriptome changes for Arabidopsis in response to salt, osmotic, and cold stress. Plant Physiol. 130:2129-2141.

24. Liang, X. Q., Holbrook, C. C., Lynch, R. E., and Guo, B. Z. 2005. 及-1,3Glucanase activity in peanut seed (Arachis hypogaea) is induced by inoculation with Aspergillus flavus and copurifies with a conglutin-like protein. Phytopathology (In Press.)

25. Lipshutz, R. J., Fodor, S. P. A., Gingeras, T. R., and Lockhart, D. J. 1999. High density synthetic oligonucleotide arrays. Nat. Gen. (Suppl.) 21:2024.

26. Livak, K. J., and Schmittgen, T. D. 2001. Analysis of relative gene expression data using real-time quantitative PCR and the $2^{-\Delta \Delta C_{T}}$ method. Methods 25:402-408

27. Luo, M., Dang, P., Guo, B. Z., He, G., Holbrook, C. C., Bausher, M. G., and Lee, R. D. 2005. Generation of expressed sequence tags (ESTs) for gene discovery and marker development in cultivated peanut (Arachis hypogaea). Crop Sci. 45:346-353.

28. Maldonado, A. M., Dorner, P., Dixon, R. A., Lamb, C. J., and Cameron, R. K. 2002. A putative lipid transfer protein involved in systemic resistance signaling in Arabidopsis. Nature 419:399-403.

29. Mekhedov, S., Martínez de Ilárduya, O., and Ohlrogge, J. 2000. Toward a functional catalog of the plant genome: A survey of genes for lipid biosynthesis. Plant Physiol. 122:389-401.

30. Moseyko, N., Zhu, T., Chang, H.-S., Wang, X., and Feldman, L. J. 2002. Transcription profiling of the early gravitropic response in Arabidopsis using high-density oligonucleotide probe microarrays. Plant Physiol. 30:720-728.

31. Nielsen, K. K., Nielsen, J. E., Madrid, S. M., and Mikkelsen, J. D. 1996. New antifungal proteins from sugar beet (Beta vulgaris L.) showing homology to non-specific lipid transfer proteins. Plant Mol. Biol. 31:539552.

32. Pinto, M. P., and Ricardo, C. P. 1995. Lupinus albus L. pathogenesisrelated proteins that show similarity to PR-10 proteins. Plant Physiol. 109:1345-1351.

33. Provart, N. J., Gil, P., Chen, W., Han, B., Chang, H.-S., Wang, X., and Zhu, T. 2003. Gene expression phenotypes of Arabidopsis associated with sensitivity to low temperatures. Plant Physiol. 132:893-906.

34. Puthoff, D. P., Nettleton, D., Rodermel, S. R., and Baum, T. J. 2003. Arabidopsis gene expression changes during cyst nematode parasitism revealed by statistical analyses of microarray expression profiles. Plant $\mathrm{J}$. 33:911-921.

35. Schena, M., Shalon, D., Davis, R. W., and Brown, P. O. 1995. Quantitative monitoring of gene expression patterns with a complementary DNA microarray. Science 270:467-470.

36. Sharma, Y. K., Hinojos, C. M., and Mehdy, M. C. 1992. cDNA cloning, structure and expression of a novel pathogenesis-related protein in bean. Mol. Plant-Microbe Interact. 5:89-95.

37. Shew, B. B., Beute, M. K., and Wynne, J. C. 1988. Effects of temperature and relative humidity on expression of resistance to Cercosporidium personatum in peanut. Phytopathology 78:493-498.

38. Shim, K. S., Kang, K. H., Chung, Y. S., Choi, H. C., Kwang, H. G., Ok, S H., Jeung, J. U., Cho, S. K., You, M. K., and Jung, K. W. 2004. Identification of fungal (Magnaporthe grisea) stress-induced genes in wild rice (Oryza minuta). Plant Cell Rep. 22:599-607.

39. Smith, D. H., Pauer, G. D. C., and Shokes, F. M. 1992. Plant diseases of international importance. Diseases of Vegetables and Oil Seed Crops, vol. II. H. S. Chaube, J. Kumar, A. N. Mukhopadhyay, and U. S. Singh, eds. Prentice Hall, Englewood Cliffs, NJ.

40. Tao, Y., Xie, Z., Chen, W., Glazebrook, J., Chang, H.-S., Han, B., Zhu, T., Zou, G., and Katagiri, F. 2003. Quantitative nature of Arabidopsis responses during compatible and incompatible interactions with the bacterial pathogen Pseudomonas syringae. Plant Cell 15:317-330.

41. Ulm, R., Ichimura, K., Mizoguchi, T., Peck, S. C., Zhu, T., Wang, X., Shinozaki, K., and Paszkowski, J. 2002. Distinct regulation of salinity and genotoxic stress responses by Arabidopsis MAP kinase phosphatase 1 . EMBO J. 21:6483-6493.

42. Vlachonasios, K. E., Thomashow, M. F., and Triezenberg, S. J. 2003. Disruption mutations of ADA2b and GCN5 transcriptional adaptor genes dramatically affect Arabidopsis growth, development, and gene expression. Plant Cell 15:626-638.

43. Whitham, S. A., Quan, S., Chang, H. S., Cooper, B., Estes, B., Zhu, T., Wang, X., and Hou, Y. M. 2003. Diverse RNA viruses elicit the expression of common sets of genes in susceptible Arabidopsis thaliana plants. Plant J. 33:271-283.

44. Wilson, R. F., Stalker, H. T., and Brummer, E. C. 2004. Legume Crop Genomics. The American Oil Chemists' Society Press, Champaign, IL.

45. Zhang, S., Nightengale, S. P., Kloepper, J. W., Wells, L. W., Reddy, M. S., and Kokalis-Burelle, N. 2001. Lack of induced systemic resistance in peanut to late leaf spot disease by plant growth-promoting rhizobacteria and chemical elicitors. Plant Dis. 85:879-884

46. Zhu, T., Budworth, P., Chen, W., Provart, N., Chang, H.-S., Guimil, S., Su, W., Estes, B., Zou, G., and Wang, X. 2003. Transcriptional control of nutrient partitioning during rice grain filling. Plant Biotechnol. J. 1:59-70.

47. Zhu, T., Budworth, P., Han, B., Brown, D., Chang, H.-S., Zou, Z., and Wang, X. 2001. Towards elucidating global gene expression in developing Arabidopsis: Parallel analysis of 8300 genes. Plant Physiol. Biochem. 39:221-242. 